\title{
High-Pressure - Low-temperature evolution in the Indus-Tsangpo Suture along the Kohistan Arc (Kaghan Valley, NE Pakistan)
}

University of Potsdam, Institute of Earth and Environmental Sciences, Karl Liebknecht Strasse 24, D-14467 Potsdam, Germany. E-mail: roob@geo.uni-potsdam.de

North of Naran in the Kaghan Valley (NE Pakistan), the metabasites of the mélange units lying below the Kohistan Arc, contain glaucophane. Typically they reflect blueschist-metamorphic conditions $\left(0.7 \mathrm{GPa}, 400^{\circ} \mathrm{C}\right)$. Associated graphite-rich metapelites with quartz veins underwent upper greenschist to amphibolite conditions. Near Naran we observed in quartz grains of type 3 veins first minute relics of $\mathrm{Fe}-\mathrm{Mg}$ carpholite indicating earlier blueschist metamorphic conditions. P-T estimates indicate 1.2-1.6 GPa at 380-410 ${ }^{\circ} \mathrm{C}$, pressure and temperature values typical for blueschist metamorphic conditions. Changes in mineral assemblages and abundant sudoite component in associated chlorite point to a pressure drop after peak I conditions. We assign the observed changes to peak I conditions occurring during a Cretaceous subduction event. Temperatures estimated with Raman graphite-thermometry clearly indicate a significant subsequent rise of post-peak I temperatures up to $500^{\circ} \mathrm{C}$. This is compatible with the amphibolite peak II assigned to the Tertiary continental collision that leads to subduction of the Indian Plate and ultra-highpressure metamorphism. During subduction the blueschist metamorphic metapelites underwent dehydration, which caused alteration in the overlying lithospheric mantle. In a hydrated lithospheric mantle density is significantly reduced which enhanced subduction of continental crust in the Higher Himalaya. This $P$-T evolution is typical for a collision orogen with a high plateau but remarkably contrasting findings from Eastern Anatolia, where plateau building is in "statu nascendi" (e.g., Oberhänsli et al., 2010).

\section{Introduction}

\section{Discovery of HP in the Himalaya}

Continental collision resulting in the formation of the Himalayan belt has long been recognized to be the result of subduction of the Indian plate below the Asian continental plate (Gansser 1964). First reports of eclogites within the higher Himalayan crystalline (Pognante and Spencer, 1991) were followed by a discovery of coesite reflecting ultra-high-pressure (UHP) conditions within the Indian plate (O'Brien et al., 2001; Mukherjee and Sachan, 2001) and glaucophane-bearing eclogites (e.g., in the upper Kaghan nappe, Lombardo and Rolfo., 2000), where glaucophane marks post-eclogite conditions. Blueschists, representing lower grade high-pressure and low-temperature $(H P-L T)$ realms are also reported along the Indus-Tsangpo Suture zone. It separates the Himalayan nappe pile to the south from the Kohistan Arc, the Ladakh and Lhasa blocks to the north with several blueschist occurrences (Fig. 1). The main suture dominated by remnants of a Tethyan accretionary wedge evolved before the continental subduction of the Indian margin (Higher Himalaya, Kaghan Valley and Ladakh). It is composed of ophiolitic mélanges and wedge type meta-pelitic to volcaniclastic metasediments.

While most subduction related $H P$ and $U H P$ rocks are known from mafic and continental rocks related to the Indian Plate in the Higher Himalaya Units, blueschists related to the accretionary wedge of the Indus Suture were only reported from mélanges so far.

Evidence of blueschists in ophiolitic mélanges was detailed from Shangla in the Swat area west of the Nanga Parbat Syntax (Shams, 1972; Desio, 1977; Bard, 1983). East of the Nanga Parbat Syntax, blueschists were reported from Ladakh (Frank et al., 1977; Virdi et al., 1977; Hoegger et al., 1989). Further to the east blueschists occur south of the Lhasa block near Sans Sang (Xiao and Gao, 1984) and eclogites in Ama Drime (Lomabrdo and Rolfo, 2000a). P-T estimates for the blueschists along the Indus-Tsampo Suture range around 0.9 - 1.1 GPa at $350-420^{\circ} \mathrm{C}$ (Honegger et al., 1989), 1.0 - 1.2 GPa at $510-600^{\circ} \mathrm{C}$ (Jan and Karim, 1995), respectively. Blueschist metamorphism in the Shangla area is determined by $0.7 \pm 0.05 \mathrm{GPa}$ at $400 \pm 20^{\circ} \mathrm{C}$ (Guiraud, 1982; Jan, 1985) and was dated to Late Cretaceous (Malusky and Matte, 1984; Anczkiewitz et al., 2000). The Shangla blueschist bearing mélanges are reported to be in contact to phyllite-schists mapped as a coherent meta-sedimentary unit assigned to the Indus Suture Zone (Anczkiewicz et al., 1998, 2000). Meta-sediments of the Tso Morari area were compared with those of the Kaghan Valley and assigned to the northern margin of the Indian Plate (Guillot et al., 1997). These meta-sedimentary units outline the Indus Suture, while blueschist bearing mélanges occur only locally. The concept that blueschist metamorphism affected oceanic material of the accretionary prism, while the Indian Plate and parts of the arc substratum suffered eclogite metamorphism (Le Fort et al., 1997) is 


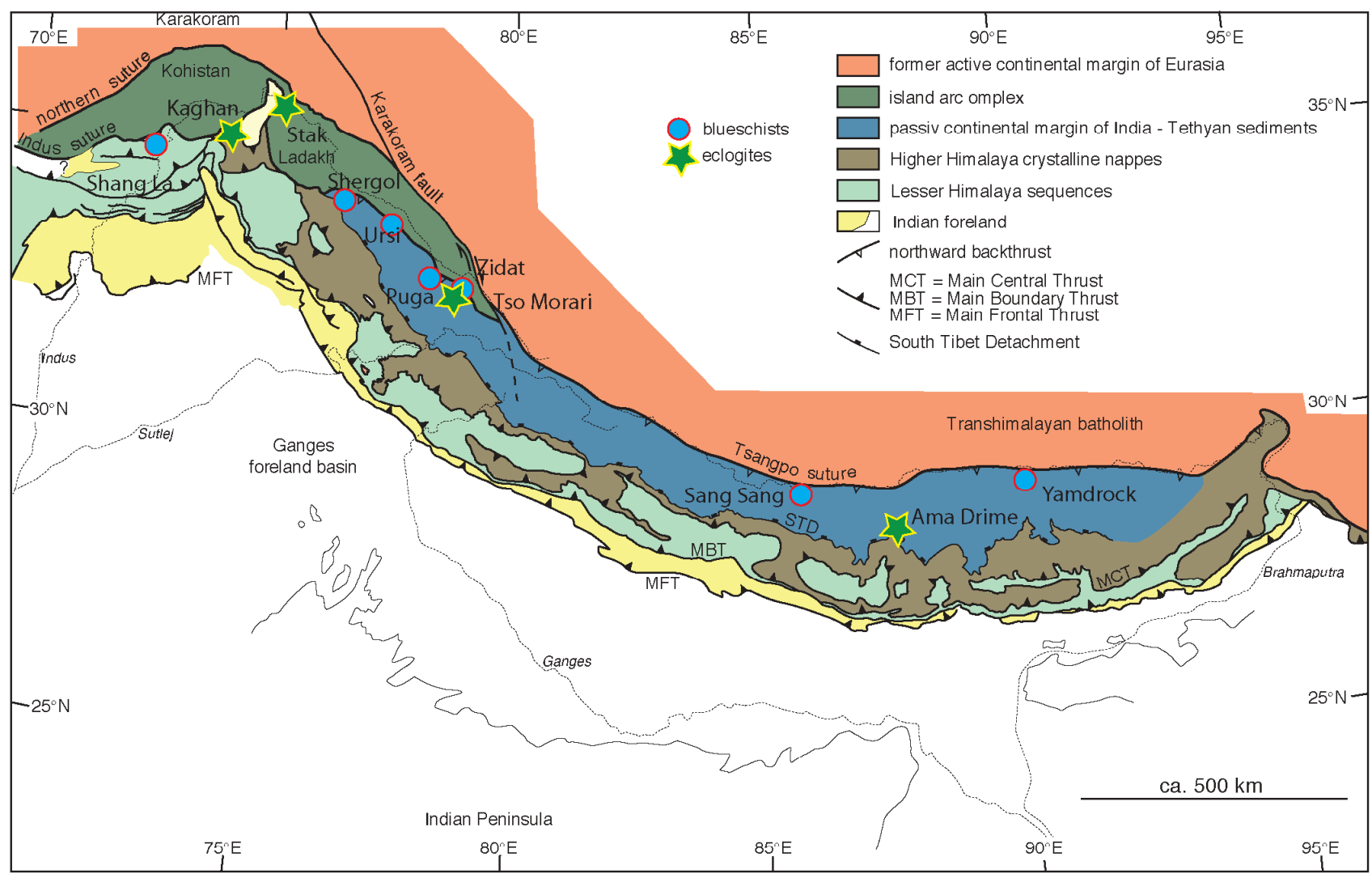

Figure 1. Geological sketch map of the Himalaya chain with indication of the known HP/UHP rocks (after Honegger et al., 1989; Pognane and Spencer, 1991; Lomabrdo et al., 2000; de Segoyer et al., 2000; Xiao \& Gao, 1984, Lombardo \& Rolfo, 2000, Guillot et al., 2008).

widely accepted, since up to now blueschist metamorphism is only reported from mélanges along the suture zone.

In this paper new data on the metamorphic history of the coherent meta-sedimentary Parla-Sapat Unit near Naran in the Kaghan Valley will show that blueschist metamorphism is wide spread along the suture even where ophiolitic mélanges are absent.

\section{Geology and metamorphic conditions of the Parla-Sapat Unit}

\section{Geological setting}

The Kaghan Valley in NE Pakistan, is built up by three major tectonic units: Lesser Himalaya, Higher Himalaya Crystalline and a mélange unit along the main mantle thrust (MMT) below the Kohistan Arc. This mélange unit comprises mafic blocks with blueschist parageneses (Shams, 1972; Bard, 1983, Anczkiewitz et al., 2000).

The mélange with blueschist bearing mafic blocks was observed to the NE towards Babusar (Bard, 1983) but apparently missing near Naran. In subsequent investigations of the Gitidas-Babusar area it was not mentioned either (Greco and Spencer, 1993; Lombardo et al., 2000, O'Brien et al., 2001, DiPietro and Pogue, 2004). Instead of ophiolitic mélanges, a coherent meta-sedimentary unit, the BannaParla-Sapat Unit (Fig. 2), consisting of graphite-rich schists with grey marbles, is distinguished (DiPietro et al., 2002). It sits below the MMT.

At Naran the units of the Lesser Himalaya and the Higher Himalaya exhibit remnants documenting a high-grade metamorphic evolution. The Lesser Himalaya meta-pelitic units hold paragenesis with garnet and staurolite, typically reflecting amphibolite-facies conditions. Rocks of the Higher Himalaya contain eclogites and relics of UHP with coesite (Pognante and Spencer, 1991; O'Brien et al., 2001; Mukherjee and Sachan, 2001, Wilke et al., 2010).

The meta-pelitic gneisses were compared to the typical graphiterich meta-sediments overprinted by Barrovian metamorphism. They contain garnet, staurolite, kyanite and diopsidic pyroxene and often show post-kinematic retrogression to greenschist-facies assemblages (Greco et al., 1989).

Uphill Damla Hamlet, a location not far from Naran, graphiterich schists in the roof of the meta-pelitic gneisses exhibit a lower metamorphic degree. They contain three types of quartz veins. Type 1 veins formed late and crosscut the country rocks and likely the earlier quartz veins. Some earlier veins (type 2 ) form sigmoidal lenses that can be associated with the main metamorphic phase. A few veins (type 3) show refolded isoclinal folds with typical fibrous quartz and mica-rich borders. The type 3 veins contain minute relics of Fe-Mg carpholite (Fig. 3) indicating earlier blueschist metamorphic conditions.

\section{Metamorphic conditions}

The graphite-rich meta-pelites of the Parla-Sapat Unit contain quartz veins/exsudates that show a conspicuous fibrous texture. The nodules are composed of quartz, calcite, white mica and chlorite. The quartz contains needles of relic carpholite, which is mostly altered to phengite and chlorite. Kyanite and chloritoid are absent.

Carpholite was identified by Raman spectroscopy and analysed 


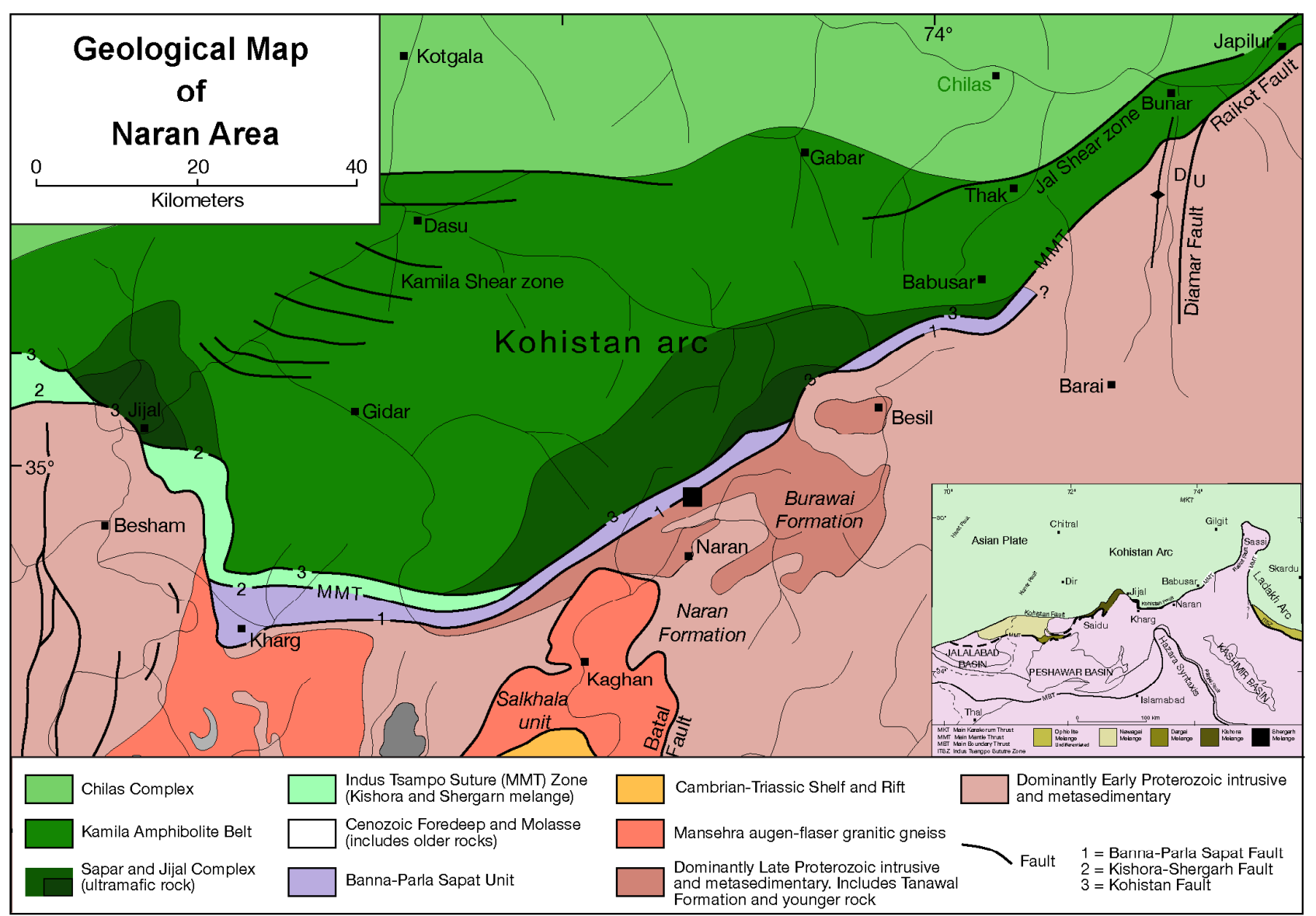

Figure 2. Geologic map of the upper Kaghan Valley showing the extension of the Banna-Parla-Sapat metasedimentary unit in which the carpholite bearing quartz veins are found. The inset map shows the position of the Naga Parbat Syntax and the relation of the Kohistan and Ladakh Arcs.

with EMPA. Due to the extremely small size $(<1 \mathrm{~mm})$ of the carpholite needles in quartz (Fig. 3), analyses always show excess quartz. Microprobe analyses were thus re-calculated according to Goffé and Oberhänsli (1992), which resulted in an average $X_{\mathrm{Mg}}$ value of 0.47 . The composition of carpholite can be given as $\mathrm{Mg}_{0.47} \mathrm{Fe}^{2+}{ }_{0.53} \mathrm{Fe}^{3+}{ }_{0.08}$ $\mathrm{Al}_{1.92} \mathrm{Si}_{2.00}\left(\mathrm{~F}_{0.07} \mathrm{OH}_{3.93}\right)$. Mineral analyses of phengite and

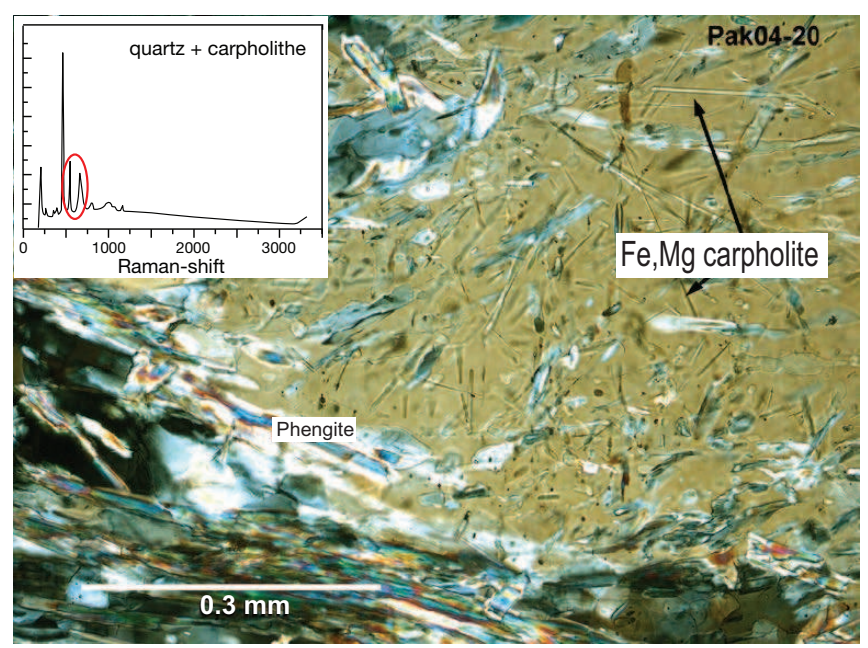

Figure 3. Photomicrograph of carpholite needles included in quartz and a Raman spectrum showing the characteristic lines of carpholite in the quartz matrix. chlorite are compiled in Table 1 and 2 and plotted in Fig.4. While the white mica embedded in the foliation planes is phengite-rich, the one assoicated to pseudomorphic carpholite or carpholite primarily enclosed in quartz shows a high pyrophyllite component. Chlorite from the carpholite-bearing assemblage is rich in the sudoite end member (Fig. 4).

Pressure and temperature estimates derived from the Si content of phengite (Oberhänsli et al. 1995) and $\mathrm{x}_{\mathrm{Mg}}$ in carpholite (Vidal et al., 1992, 1996) indicate $1.2-1.6 \mathrm{GPa}$ at $380-410{ }^{\circ} \mathrm{C}$ (Fig. 5). These values can be assigned texturally to early pressure peak metamorphic conditions $(\boldsymbol{P} I)$. The lack of chloritoid and or kyanite as well as abundant sudoite components in post-carpholite chlorite points to a pressure drop below $\sim 0.6 \mathrm{GPa}$ outside the stability field of carpholite after $\boldsymbol{P} \boldsymbol{I}$ conditions. Temperatures estimated with Raman graphite-thermometry (Beyssac et al., 2002; Rahl et al., 2005) in the graphite-rich schist containing the type 3 quartz veins clearly indicate a significant rise of post-P $\boldsymbol{I}$ temperatures up to $500^{\circ} \mathrm{C}$. This is compatible with reported amphibolite conditions for rocks in the Lesser Himalaya (Greco and Spencer, 1993; Smith et al., 1994).

\section{Discussion}

The new P-T estimates are in contrast to earlier estimates. Values for blueschists from Shangla $\left(0.7 \mathrm{GPa}, 400^{\circ} \mathrm{C}\right.$; Guiraud, 1982; Jan, 1985), the Parla-Sapat Unit (0.4 - 0.8 GPa, 380 - $480^{\circ} \mathrm{C}$; Smith, 1994) 
Table 1. Representative analyses of white mica and chlorite from quartz veins of the graphite-rich meta-pelites of the Parla-Sapat Unit. Fe is calculated as ferric and total kations are normalized to 11 oxides.

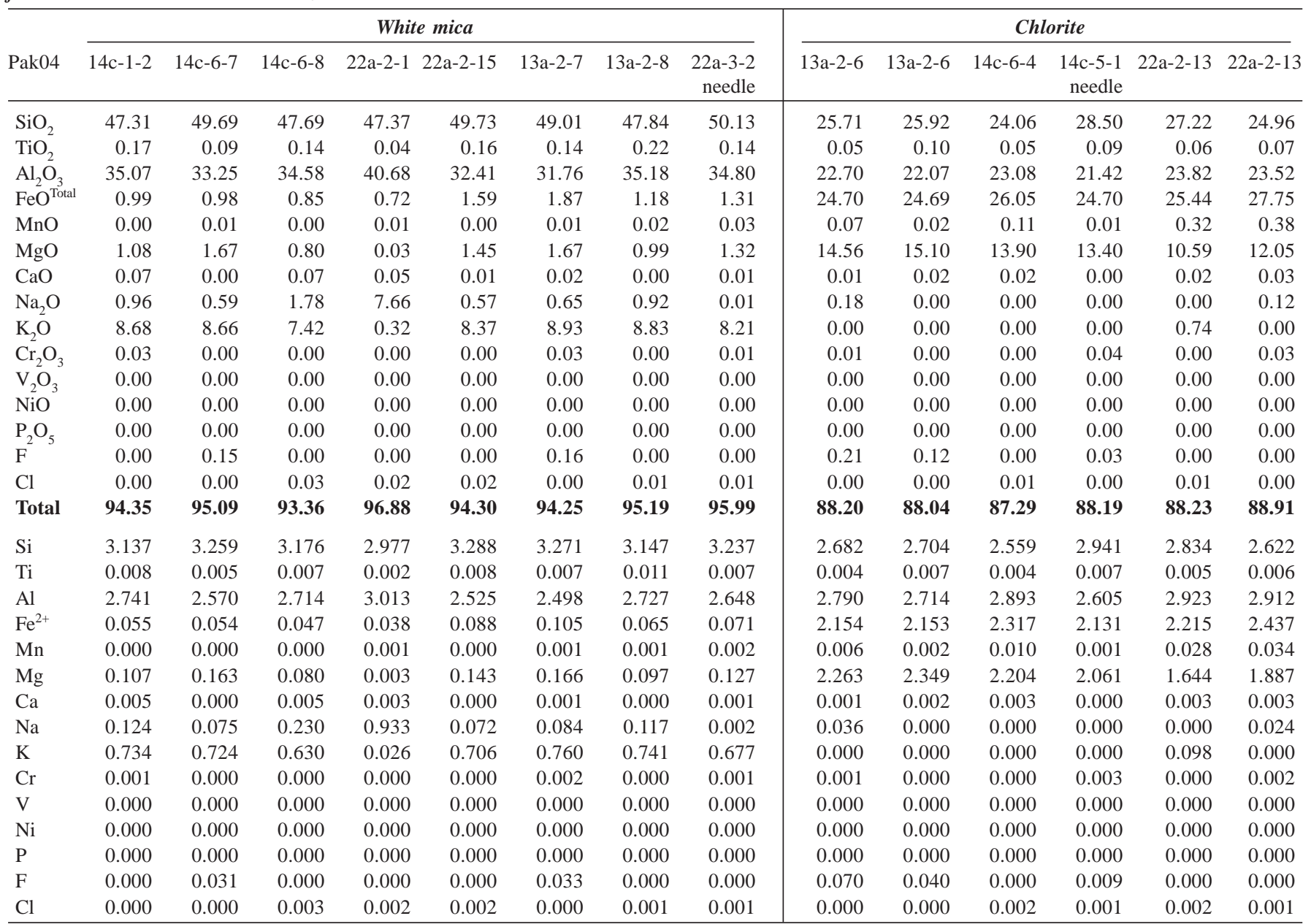

or the Batal Thrust $\left(1 \mathrm{GPa}, 540{ }^{\circ} \mathrm{C}\right.$; Smith 1994) are mostly considerably lower. They also differ significantly from the Higher Himalayan crystalline rocks $\left(0.9 \pm 0.2 \mathrm{GPa}, 650^{\circ} \mathrm{C}\right.$; Treolar 1998) or the $U H P$ eclogites (2.7 - 2.9 GPa, 690-750; O'Brien et al., 2001) and glaucophane eclogites (2.4 GPa, $610^{\circ} \mathrm{C}$; Lombardo et al., 2000).

The metamorphic age of the Shangla blueschists was at first

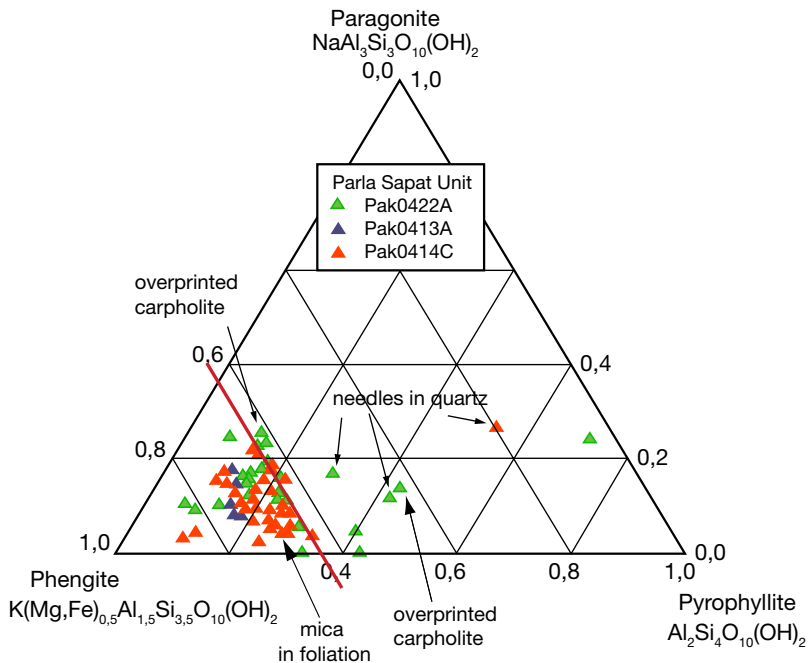

determined with K/Ar method to $84 \pm 1.7 \mathrm{Ma}$ (Shams, 1980). Later laser-Ar analyses on fine glaucophane needles revealed $65 \pm 15 \mathrm{Ma}$, while the Ar stepwise heating method yielded on phengites $75 \pm 5$ Ma and $80 \pm 10 \mathrm{Ma}$ (Maluski and Schäfer, 1982) and 83.5 $\pm 2 \mathrm{Ma}$, respectively (Maluski and Matte, 1984). Phengite ${ }^{39} \mathrm{Ar} /{ }^{40} \mathrm{Ar}$ ages of 80 Ma were finally interpreted as metamorphic peak age (Anczkiewitz

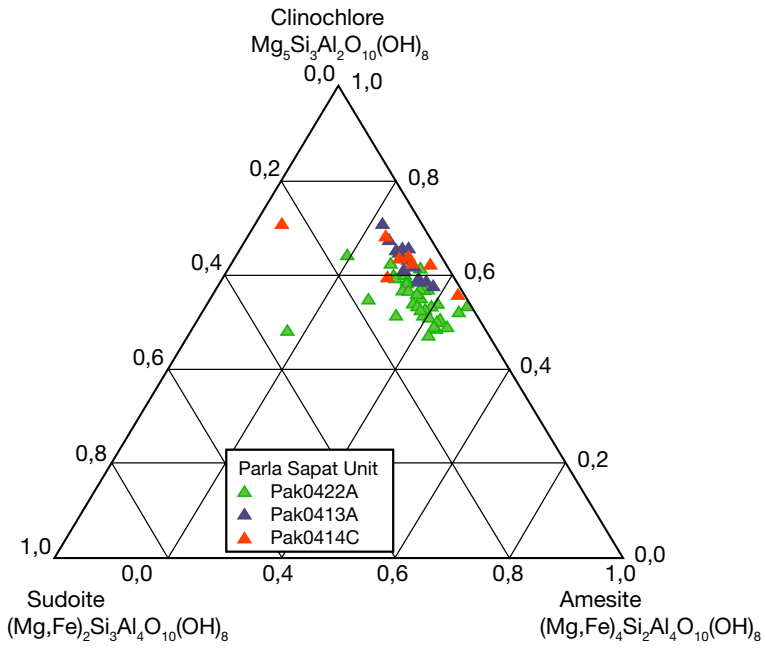

Figure 4. Trinagular plots for white mica and chlorite from the carpholite bearing quartz veins in graphite rich metapelites from the Parla Sapat Unit. 
et al., 2000). These ages clearly contrast with the Tertiary ages (ca. 55 Ma; De Sigoyer et al., 2000; Leech et al., 2005) determined for the $H P$ and $U H P$ eclogites of the Higher Himalaya crystalline basement of the Tso Morari complex. For the UHP unit in the Kaghan Valley Wilke et al. (2010) published a $P-T-t$ path assigning $47.4 \pm 0.5$ Ma to the $U H P$ event, and 46 to $41 \mathrm{Ma}$ to the post-eclogitic exhumation of the mantle. At ca. $41 \mathrm{Ma}$ a phase of stagnation occurred heating the rocks by more than $100{ }^{\circ} \mathrm{C}$ at/in the lower crust. After this thermal peak greenschist-facies minerals were dated to 31.7 - 34.5 Ma reflecting the crustal exhumation (Wilke et al., 2010). The $P-T$ evolutions for the two UHP areas are in good agreement.

\section{Significance of Fe,Mg-carpholite occurrence}

P-T conditions $\left(0.7 \mathrm{GPa}, 400^{\circ} \mathrm{C}\right)$ presented for the Shangla rocks (Guiraud, 1982; Jan, 1985) are clearly influenced by retrograde processes or even significantly overprinted by a second metamorphic event $(\boldsymbol{P} I I)$. The published P-T values do not point to real blueschistmetamorphic condition, while the mineral assemblage clearly does. Contrastingly the $\mathrm{Fe}, \mathrm{Mg}$ carpholite relicts from vein type 3 and the lack of either kyanite or chloritoid as well as the abundant sudoite component in chlorite of the graphite-rich meta-pelites of the BannaParla-Sapat Unit point to a blueschist HP-LT peak and a rapid decompression typically associated with exhumation processes in an accretionary wedge during subduction. The dynamic setting, in combination with the ages reported for the different blueschists, eclogites and $U H P$ rocks allows to separate the two metamorphic events (PI, PII), with their respective $P$ - $T$ paths (Fig. 5). The graphiterich meta-pelites of the Parla-Sapat Unit as well as the Shangla blueschist record an early subduction stage in an accretionary wedge setting with an early, Cretaceous, almost isothermal exhumation. However, only the armoured relics of carpholite, white mica and chlorite included in quartz of syn-metamorphic veins record the pressures at peak conditions.

The glaucophane-bearing parageneses of the Shangla blueschists show the effect of retrogression during the subsequent collision stage, which was leading to amphibolite-facies conditions. Similarly the Lesser and Higher Himalaya rocks of the Indian plate, record mainly the later Tertiary collision phase that brought continental crust to various depths. Peak conditions and exhumation paths deduced from UHP rocks (Wilke et al., 2010) indicate that the rocks were amalgamated with other parts of crustal rocks showing amphibolitefacies conditions. This is recorded by significantly different P-T evolutions (Fig. 5). The identification of carpholite inclusions in quartz veins allows a better characterisation of the two-step $H P$-evolution in the Khagan region. Moreover the juxtaposition of the Tertiary HP/ $U H P$ unit to the Cretaceous blueschist unit at mid crustal levels during exhumation at ca. 44-41 Ma (Wilke et al., 2010) is evidenced.

The occurrence of $\mathrm{Fe}, \mathrm{Mg}$ carpholite relicts within the BannaParla-Sapat Unit points to blueschist-facies overprint of the entire meta-sedimentary section and not only of the mafic portions in the mélange zones. The meta-pelitic low-grade high-pressure sediments contain characteristic associations of subduction related metamorphism similar to other collision orogens such as the Bethics, the Western Alps or Anatolia. The sediments of the Banna- ParlaSapat Unit point to an extended blueschist belt along the Indus-Tsampo Suture zone in the Kaghan Valley that possibly spreads all along the suture zone towards east. This assumption is based on observations form the Tethyan realm in the Alps and especially in Anatolia where

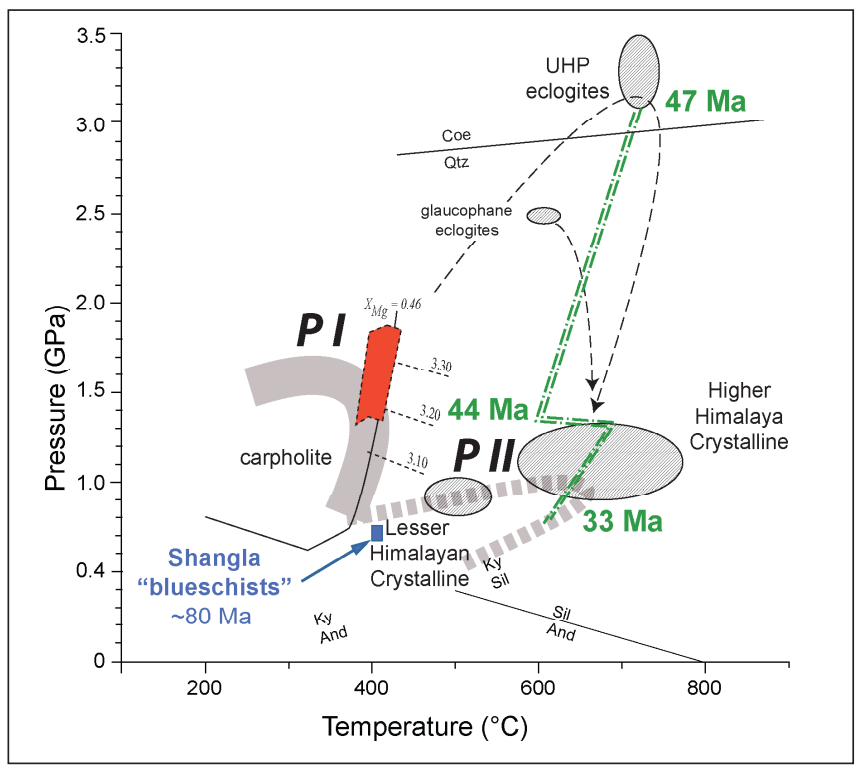

Figure 5. Synthetic P-T Diagram showing the P-T data deduced from carpholite relicts using Oberhänsli et al. (1995). The high-T side of the stability field of carpholite is constrained by $X_{M g}$ Carph according to the experimental work of Vidal et al. (1992). The dark gray field represents the compositional variation in the Kaghan rocks the light grey bow a possible P-T evolution. Numbered dotted lines indicate Si content in phengite. Blue square: P-T Estimate for the Shangla blueschists (Guiraud, 1982; Jan, 1985) with a metamorphic age of $\sim 80 \mathrm{Ma}$ (Anczkiewicz et al., 2000). The grey ellipses cover representative $P-T$ space compiled from published data for Lesser and Higher Himalaya (Smith 1994), the glaucophane eclogites (Lombardo et al., 2000) and the UHP rocks (Treolar 1998; $O$ 'Brien et al., 2001). Simple dashed line indicates suggested P-T paths. Double dashed line represents the P-T Evolution for the UHP rocks in the Kaghan Valley after Wilke et al. (2010).

recently an extensive $H P$ belt of over $600 \mathrm{~km}$ length characterised by carpholite was identified (Candan et al., 2005, Pourteau et al., 2010).

The observation of carpholite in the Himalaya adds to the record of Tethyan blueschist-facies meta-sediments (Fig. 6). They stretch from the Rif in Morocco to New Caledonia. However, the absence of $\mathrm{Fe}, \mathrm{Mg}$ carpholite in Iran remains enigmatic. Besides the late Cretaceous to Tertiary meta-sediments of the Tethyan realm carpholite was also reported from Palaeozoic rocks of Svalbard (Agard et al, 2005) and the North Qilian suture zone (Song et al., 2007). Yet no $\mathrm{Fe}, \mathrm{Mg}$ carpholite has been found along the circum-Pacific subduction belt with its volcanic arcs. This must be attributed to the volcaniclastic nature of the sediments and their high sodium, low potassium content. Up to now $\mathrm{Fe}, \mathrm{Mg}$ carpholite associated with albite was not observed.

Models of crustal collision and crustal flow assign fluids, which enhance flow, an important role. The observation from the Kaghan Valley, corroborates these hypotheses. The area consists of three tectonic units: Lesser Himalaya, Higher Himalaya and a mélange unit associated with meta-sedimentary units below the Main Mantle thrust of the Kohistan arc. Around Naran the first two units exhibit remnants of a high-grade metamorphic evolution. The Lesser Himalaya metapelitic units hold paragenesis with garnet and staurolite, typically indicating amphibolite facies conditions. Rocks of the Higher Himalaya contain Tertiary eclogites and relics of UHP with coesite. During Cretaceous subduction the wedge sediments, represented by 


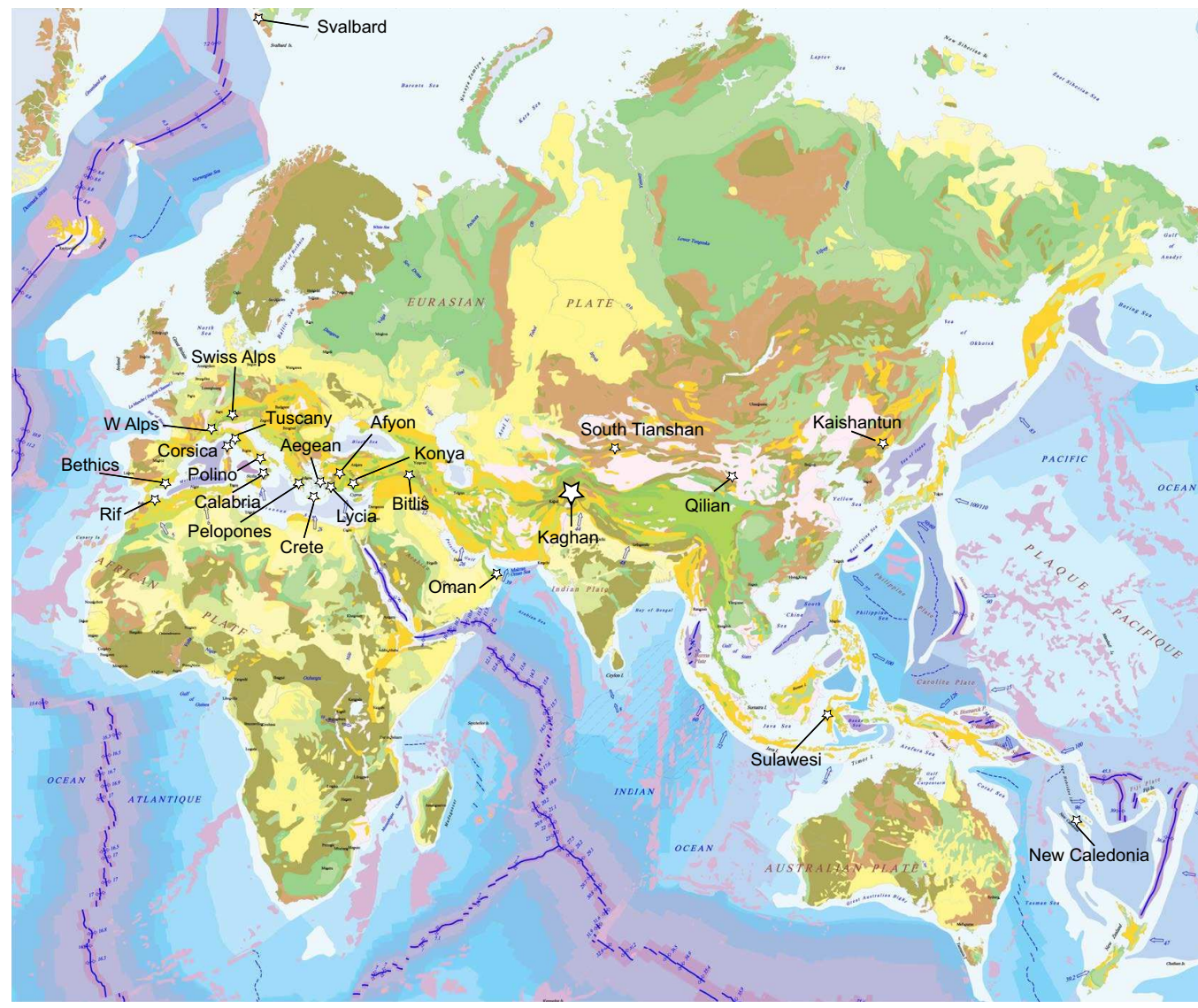

Figure 6. Compilation of world wide carpholite occurrences, showing its dominant distribution along the Tethyan realm.

the Banna- Parla- Sapat Units along the Kohistan Arc, underwent significant dehydration. By integration into an accretionary wedge, deep-seated portions of the wedge sediments (not exhumed) allowed for the incorporation of water-rich fluids into the overlying lithospheric mantle. The rheologic behaviour of a probably amphibole and or phlogopite bearing hydrated mantle, with a significantly lower density (>5 \%, Bousquet and Oberhänsli, 2010), is possibly a prerequisite but surely enhanced later subduction of the Indian continental crust.

A template for the situation in the Himalayas, where after the subduction events continent - continent collision finally lead to building of a high plateau, can be identified in eastern Anatolia where the plateau formation is still in "statu nascendi". At this location the Arabian continental crust it just about to impinge with the Eurasian continental plate. For Eastern Anatolia the carpholite bearing metasediments of the Bitlis Complex indicate a rapid, cold exhumation (Oberhänsli et al., 2010). A successive second event representing greenschist- to amphibolite-facies conditions has yet to develop or to be exposed along the Arabian indenter, while it is already expressed in the Southern Caucasus where the south Armenian Block collided with the Eurasian plate (Rolland et al., 2008; Oberhänsli et al. 2011).

\section{Conclusions}

The occurrence of carpholite in the graphititc metapelites of the Parla-Sapat Unit near Naran in the Kaghan Valley associated with the ophiolitic mélanges along the Indus-Tsampo suture indicate a much wider extension of a blueschist belt along the suture.

The identification of minute carpholite inclusions surviving later high-temperature meta- morphic evolution in quartz veins allowed to characterize the two-step $H P$ evolution of the Khagan region and documents the juxtaposition of the Tertiary HP/UHP unit to the Cretaceous blueschist unit within the subduction channel. It is noteworthy that the blueschist from the mélanges do not preserve the Cretaceous $H P$ peak but only stored the post- $H P$ evolution.

With the new data presented, a clear distinction between the subduction event forming blueschists and the later collision event producing amphibolite/ migmatite is possible. This dual peak metamorphic evolution is representative for an area in progressing full continent continent collision such as the Himalaya

\section{Acknowledgements}

I thank A Riemann for her help with analytical work, Romain Bousquet and Patrick O'Brien for their discussions and of course C. Fischer who produced as many thin sections as needed to find relicts of carpholite big enough to be analysed.

\section{References}

Agard, P., Labrousse, L., Elvevold, S., and Lepvrier, C., 2005, Discovery of Palaeozoic Fe-Mg carpholite in Motalafjella, Svalbard Caledonides: a milestone for subduction-zone gradients: Geology, v. 33, pp. 761-764.

Anczkiewicz, R., Burg, J.P, Hussain, S.S., Dawood, H., Ghazanfar, M., and Chaudhry, M.N., 1998, Stratigraphy and structure of the Indus Suture Zone in the Lower Swat, Pakistan, NW Himalaya: Journal Asian Earth Sciences, v. 16, pp. 225-238.

Anczkiewicz, R., Burg, J.P., Villa, I.M., and Meier, M., 2000, Late Cretaceous blueschist metamorphism in the Indus Suture Zone, Shangla region, Pakistan Himalaya: Tectonophysics, v. 324, pp. 111-134

Bard, J.P., 1983, Metamorphism of an obducted island arc: example of the Kohistan sequence (Pakistan) in the Himalayan collided range: Earth Planetary Science Letters, v. 65, pp. 133-144.

Beyssac, O., Goffé, B., Chopin, C., and Rouzaud, J.N., 2002, Raman spectra of carbonaceous material in metasediments: a new geothermometer: Journal Metamorphic Geology, v. 20, pp. 859-871.

Desio, A., and Shams, F.A., 1980, The age of blueschists and the Indus Kohistan Suture line, NW Pakistan: Proceedings Italian Academy of Sciences, v. 68, pp. 74-79.

Desio, A., 1977, The occurrence of blueschists between the middle Indus and eth Swat valleys as an evidence of subduction in northern Pakistan: Rendic. Accad. Nazz. Lincei, v. 52, pp. 1-9.

Di Pietro, J.A., and Pogue, K.R., 2004, Tectonostratigraphic subdivisions of the Himalaya: A view from the west: Tectonics, v. 23, TC5001, doi:10.1029/2003TC001554.

Di Pietro, J.A., Hussain, A., Ahmad, I., and Khan, M.A., 2000, The main mantle Thrust in Pakistan: its character and extent, in Khan, M.A., Treloar, J.A., Searle, M.P. and Jan, M., eds, Tectonics of the Nanga Parbat Syntaxis 
and the western Himalaya: Geological Society of London, Special Publication, v. 170, pp. 375-393.

Frank, W., Gansser, A., and Trommsdorff, V., 1997, Geological observations in the Ladakh area (Himalaya). A preliminary report: Schweiz. Mineral. Petrogr. Mitt., v. 57, pp. 89-113.

Gansser, A., 1964, Geology of the Himalayas. Wiley, London.

Goffé, B., and Oberhänsli, R., 1992, Ferro-magnesiocarpholite in the "Bündnerschiefer" of the eastern Central Alps (Grisons and Engadine window): European Journal of Mineralogy, v. 4, pp. 835-838.

Greco, A., Martinotti, G., Papritz, K., Ramsey, J.G., and Rey, R., 1989, The crystalline rocks of the Kaghan Valley (NE Pakistan): Eclogae Geol. Helv., v. 82, pp. 629-653.

Greco, A., and Spencer, D.A., 1993, A section through the Indian Plate, Kaghan Valley, NW Himalaya, Pakistan, in Treloar, P.J., and Searle, M.P., eds, Himalayan Tectonics: Geological Society of London, Special Publication, v. 74, 221-236

Guillot, S., de Sigoyer, J., Lardeaux, J.M., and Mascle, G., 1997. Eclogitic metasediments from the Tso Morari area (Ladakh, Himalaya): evidence for continental subduction during India-Asia convergence. Contribution to Mineralogy and Petrology, v. 128, pp. 197-212.

Guillot, S., Mahéo, G., de Sigoyer, J., Hattori,K.H. and Pêcher, A. 2008 Tethyan and Indian subduction viewed from the Himalayan high- to ultrahighpressure metamorphic rocks. Tectonophysics, v. 451, pp. 225-241.

Guiraud, M., 1982, Géothermobarométrie du faciès schiste vert à glaucophane. Modelisation et applications (Afghanistan, Pakistan, Corse, Bohème): Ph.D. thesis, Montpellier University.

Honegger, K., Le Fort, P., Mascle, G., and Zimmermann, J-L., 1989, The blueschists along the Indus Suture Zone in Ladakh, NW Himalaya: Journal of Metamorphic Geology, v. 7, pp. 57-72.

Jan, M.Q., 1985, High-P rocks along the suture zones around Indo-Pakistan plate and phase chemistry of blueschists from eastern Ladakh: Geological Bulletin of the University of Peshawar, Pakistan, v. 18, pp. 1-40.

Jan, M.Q., and Karim, A., 1995, Coronas and high-P veins in metagabbros of the Kohistan island arc, northern Pakistan: evidence for crustal thickening during cooling: Journal of Metamorphic Geology, v. 13, pp. 357-366.

Le Fort, P., Guillot, S., and Pêcher, A., 1997, HP metamorphic belt along the Indus suture zone of NW Himalaya: new discoveries and significance: Comptes Rendus Academie des Sciences. Paris, Sciences de la terre et des planètes / Earth \& Planetary Sciences, v. 25, pp.773-778.

Leech, M.L., Singh, S., Jain, A.K., Klemperer, S.L., and Manickavsagam, R.M., 2005, The onset of India-Asia continental collision: Early steep subduction required by the timing of UHP metamorpjhhism in the western Himalaya: Earth Planetary Science Letters, v. 234, pp. 83-97.

Lombardo, B., and Rolfo, F., 2000. Two contrasting eclogite types in the Himalayas:implications fror the Himalayan orogeny. Journal of Geodynamics, v. 30, pp. 37-60.

Lombardo, B., Rolfo, F., and Comagnoni, R., 2000, Glaucophane and barrosite eclogites from upper Kaghan nappe: implications for the metamorphic history of the NW Himalaya, in Khan, M.A., Treloar, J.A., Searle, M.P. and Jan, M., eds, Tectonics of the Nanga Parbat Syntaxis and the western Himalaya: Geologial Society of London, Special Publicaiton, v. 170, pp. $375-393$

Maluski, H., and Matte, P., 1984, Ages of Alpine tectonometamorphic events in the northwestern Himalaya (Northern Pakistan) by ${ }^{39} \mathrm{Ar} /{ }^{40} \mathrm{Ar}$ : Tectonics, v. 3, pp. $1-18$.

Maluski, H., and Schäffer, O.A., 1982, ${ }^{39} \mathrm{Ar}-{ }^{40} \mathrm{Ar}$ laser probe dating of terrestrial rocks: Earth Planetary Science Letters, v. 59, pp. 21-27.

Mukherjee, B.K., and Sachan, H. K., 2001, Discovery of coesite from Indian Himalaya: A record of ultra-high pressure metamorphism in Indian Continental Crust: Current science, v. 81, pp. 1358-1361

O'Brien, P.J., Zotov, N., Law, R.D., Khan, M.A. and Jan, M.Q., 2001, Coesite in Himalayan eclogite and implications for models of India-Asia collision: Geology, v. 29, pp. 435-438.

Oberhänsli, R., Goffé, B., and Bousquet, R., 1995, Record of a HP-LT metamorphic evolution in the Valais zone: Geodynamic implications: Bolletino del Museo Regionale delle Scienze naturali Torino., v. 13, pp.221-240.

Oberhänsli, R., Candan, O., Bousquet, R., Rimmele, G., Okay, A., and Goff, J., 2010, Alpine HP Evolution of the eastern Bitlis complex, SE Turkey, in Sosson M., Kaymakci N., Stephenson R., Strarostenko V. and Bergerat F., eds, Sedimentary basins, tectonics from Black Sea an Caucasus to the
Arabian plateform: Geol. Soc. London, Spec. Pub., v. pp. 340, 461-483. Oberhänsli, R., Bousquet, R., Candan, O. and Okay, A. I., 2011, Dating Subduction Events in East Anatolia. Turkish Journal of Earth Sciences, v. 21, pp. 1-17. doi: 10.3906/yer-1006-26.

Rahl, J.M., Anderson, K.M., Brandon, M.T., and Fassoulas, C., 2005, Raman spectroscopic carbonaceous material thermometry of low-grade metamorphic rocks: Calibration and application to tectonic exhumation in Crete, Greece: Earth Planetary Science Letters, v. 240, pp. 339-354.

Rolland, Y., Billo, S., Corsini, M., Sosson, M. and Galoyan, G., 2008, Blueschists of the Amassia-Stepanavan Suture Zone (Armenia): linking Tethys subduction history from E-Turkey to W-Iran. International Journal of Earth Sciences, v. 98, pp. 533-550.

Shams, F.A., 1972, Origin of Shangla blueschist, Swat Himalaya, Pakistan: Geological Bulletin of the University of Peshawar, v. 13, pp. 67-70.

Shams, F.A., 1980, Origin of the Shangla Blueschist, Swat Himalaya, Pakistan: Geological Bulletin of the University of Peshawar, Pakistan, v. 13, pp. 67-70.

Smith H.A., Chamberlan C., and Zeitler P.K., 1994, Timing and duration of Himalayan metamorphism within the Indian Plate, Northwest Himalaya, Pakistan: Journal of Geology, v. 102, pp. 493-508

Song, S.G., Zhang, L.F., Niu, Y., Wei, C.J., Liou, J.G., and Shu, G.M., 2007, Eclogite and carpholite-bearing metasedimentary rocks in the North Qilian suture zone, NW China: implications for Early Palaeozoic cold oceanic subduction and water transport into mantle: Journal of Metamorphic Geology, v. 25, pp. 547-563, doi:10.1111/j.1525-1314. 2007.00713.x

Vidal, O., Goffeì, B., and Theye, T., 1992, Experimental study of the stability of sudoite and magnesiocarpholite and calculation of a new petrogenetic grid for the system $\mathrm{FeO}-\mathrm{MgO}-\mathrm{Al}_{2} \mathrm{O}_{3}-\mathrm{SiO}_{2}-\mathrm{H}_{2} \mathrm{O}$ : Journal of Metamorphic Geology, v. 10, pp. 603-614.

Vidal, O., Goffe ì, B., Bousquet, R., and Parra, T., 1999, Calibration and testing of an empirical chloritoid-chlorite $\mathrm{Mg}$-Fe-exchange thermometer and thermodynamic data for daphnite: Journal of Metamorphic Geology, v. 17 , pp. $25-39$.

Virdi, N.S., Thakur, V.C. and Kumar, S., 1977, Blueschist facies metamorphism from the Indus Suture Zone of Ladakh and its significance: Himalayan Geologist, v. 7, pp. 479-482.

Wilke, F.D.H., O'Brien, P.J., Gerdes, A., Timmerman, M.J., Sudo M., and Khan, M. A., 2010, The multistage exhumation history of the Kaghan Valley UHP series, NW Himalaya, Pakistan from U-Pb and 40Ar/39Ar ages: European Journal of Mineralogy, v. 22, pp.703-719.

Xiao, C.C., and Gao, Y.L., 1984, Tectonic evolution of the Tethys-Himalaya of China: Tectonics of Asia, Colloq. No 5, $27^{\text {th }}$ International Geology Congress, Moscow. Reports, v. 5, pp. 181-189.

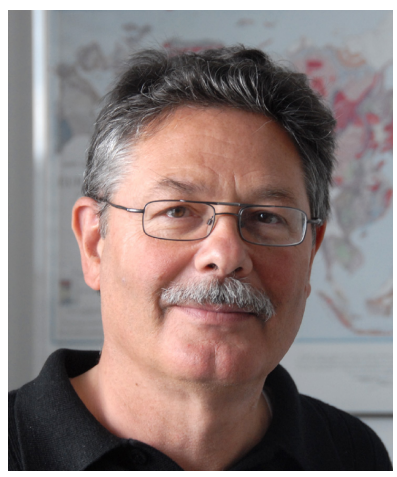

Roland Oberhänsli is Professor of mineralogy at the Institute of Earth \& Environmental Sciences of Potsdam University in Germany. He is a metamorphic petrologist working on Tethyan HP rocks from the Alps to the Himalaya. He serves as coordinator of the German National ICDP program and as President for magmatic and metamorphic maps at the Commission of the Geological Map of the World CGMW. Currently he is the President of the IUGS. 